\title{
Fipa Furnaces and Slag: Distinguishing Criteria Based on Physical Analysis
}

\author{
John Uche Ngonadi', Pamela Ifeoma Eze-Uzomaka ${ }^{2}$ \\ Department of Archaeology and Tourism, University of Nigeria, Nsukka, Nigeria \\ Email: jungonadi@gmail.com, drpamela26@yahoo.com
}

Received 10 December 2014; accepted 5 January 2015; published 13 January 2015

Academic Editor: David A. Aremu, Department of Archaeology and Anthropology, University of Ibadan, Nigeria

Copyright (C) 2015 by authors and Scientific Research Publishing Inc.

This work is licensed under the Creative Commons Attribution International License (CC BY).

http://creativecommons.org/licenses/by/4.0/

(c) (i) Open Access

\begin{abstract}
Excavations and ground reconnaissance in December 2009 at Sumbawanga district, in southwestern Tanzania, revealed complete remains of natural draft iron smelting furnaces locally called ilungu (sing.) or malungu (pl.) standing up to 2.8 - $3.1 \mathrm{~m}$ tall. The aim of the study was to identify remains of indigenous African iron smelting furnaces on the landscape of Fipaland, examine the slag from the identified furnaces as very little amount of attention has been paid to furnace structures and analysis of the resultant residues. It has been usually studied in isolation of one of the order, while more attention was paid to furnace types; less has been done on slag analysis; in order to make for more reliable identification and develop a criteria for distinguishing this fast disappearing cultural heritage.
\end{abstract}

\section{Keywords}

Fipa, Malungu, Iron Working, Smelting, Refining, Furnaces, Slag

\section{Introduction}

An excavation of iron smelting sites was carried out among the Fipa of Miangarua village, Sumbawanga District in Rukwa Region in December 2009 with the aim to understand the relationship between malungu furnace structure and its resultant slag which is more ubiquitous compared to the furnace that produce it in order to establish criteria to distinguish between same technology based on physical composition. Prior to this study, Ufipa was archaeometallurgically poorly known except for the research conducted by Mapunda (1995, 2003) and Barndon (1992, 2001). The Fipa iron working technology a three staged process has been documented by travelers, colonial administrators and missionaries alike and has been observed and studied by ethnographers and 
archaeologists in the twentieth century (Lechaptois, 1913, Wyckaert, 1914, Greig, 1937, Robert, 1949, Wise, 1958a, 1958b; Willis, 1966, 1981; Wembah-Rashid, 1969, Mapunda, 1995, 2003, 2010; Barndon, 1992, 2001; Ngonadi, 2010). The first stage is the primary smelting conducted in three different furnaces: The earliest is the globular, Katukutu, dated to between 1550 and $1800 \mathrm{AD}$; the high shaft, Malungu, an impressive 2 - $4 \mathrm{~m}$ tall furnace and the low shaft generally classified as Type C furnaces (Childs, 1991; Kense, 1983), Barongo, are dated to later than the mid-nineteenth century AD. Brown ores of limonite and hematite were reduced in these furnaces fuelled by charcoal and green wood. The second stage was the secondary refining carried out in a smaller forced air draft furnace, ichiteengwe, varying in height of $40-50 \mathrm{~cm}$ and of the B type. This furnace was used in order to consolidate the bloom and was operated by three bag bellows of goatskin connected to bamboo sticks and tuyère made of clay. The third stage was the forging, ukusula, of iron, ulolo, into objects. The forging was conducted over an open fire or a small three-walled stone forge. The Fipa forge, impeembe, was a grassthatched hut located within the village (Mapunda, 1995; Barndon, 1992). Two of the same bellows, umwuuwa, that were used in the secondary refining furnace were also used during forging (Barndon, 2001: p. 2).

\section{Ufipa Iron Smelting Furnaces}

Three Malungu furnaces were identified with the kind assistance of Nzei Mlaya at Miangarua village in Mpui Ward of Sumbawanga District (see Figure 1). Located on the plateau, two of these were complete while the other furnace had disintegrated. These still standing iron smelting furnaces are about $2.75-3.09 \mathrm{~m}$ high. In Kukumo village, at the escarpment, we located two still standing Malungu furnaces. The former is located on latitude $08.40854^{\circ} \mathrm{S}$ and longitude $031.66304^{\circ} \mathrm{E}$ at an elevation of $1922 \mathrm{~m}$ above sea level and is $3.09 \mathrm{~m}$ high from the ground surface with an exterior basal diameter of $5.60 \mathrm{~m}$ (Ngonadi, 2010, 2011). The latter in Itekesya (or Itekesha) community is geographically situated within latitude $08.41816^{\circ} \mathrm{S}$ and longitude $031.66953^{\circ} \mathrm{E}$, on an elevation of $1931 \mathrm{~m}$. This was $2.79 \mathrm{~m}$ high from the southern corner and $3.17 \mathrm{~m}$ from the northern corner with an exterior basal diameter of $4.95 \mathrm{~m}$. Each furnace had a peep-hole facing east, measuring $3-4.5 \mathrm{~cm}$ in diameter with 10 tuyère ports. More so, two visible furnace remains were identified on the surrounding landscape. One was the remains of kintengwe with evidence of flow slag littered around it (a miniature iron refining furnace)

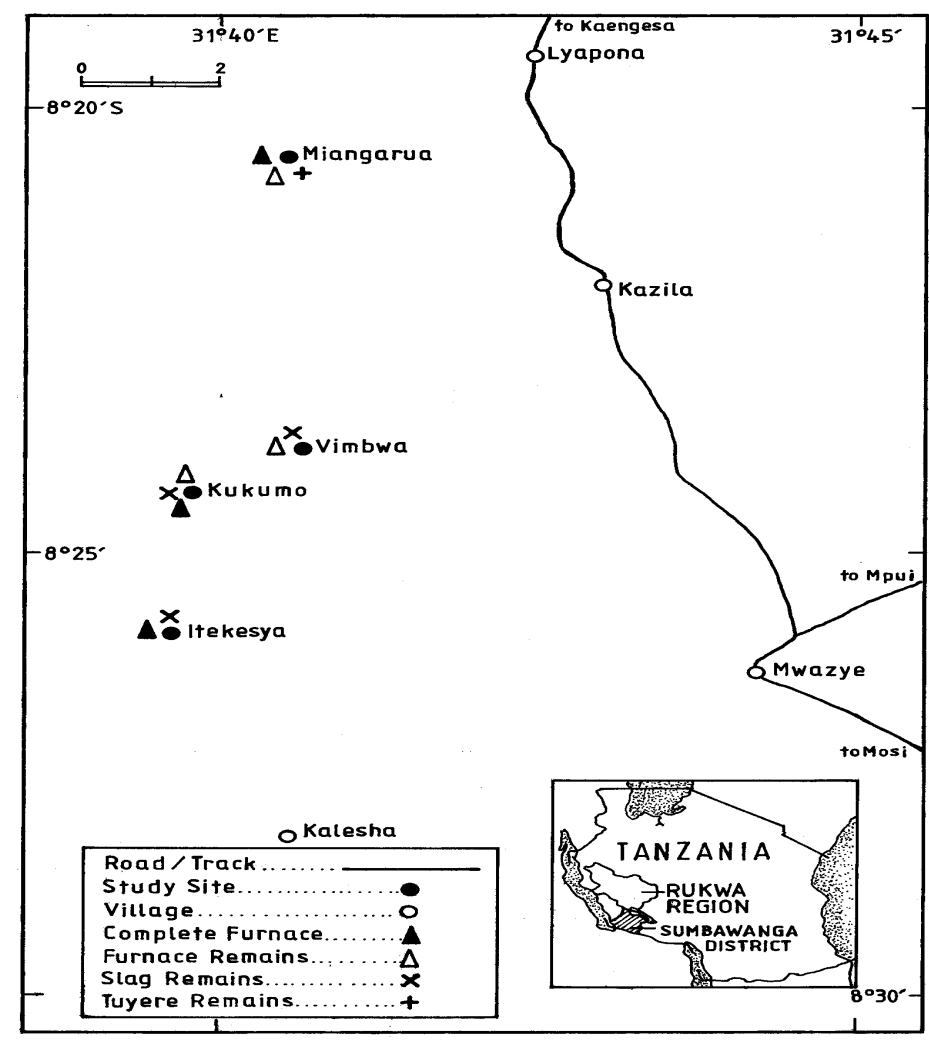

Figure 1. Map of Sumbawanga district showing the study areas. 
found in Vimbwa village (Figure 2). The geographical coordinates of this site which lies on the slope of a hill is on latitude $08.39919^{\circ} \mathrm{S}$ and longitude $031.66690^{\circ} \mathrm{E}$ with a ground elevation of $1963 \mathrm{~m}$ above sea level. The other was an Ilungu iron smelting furnace in Kukumo village which lies on latitude $08.40999^{\circ} \mathrm{S}$ and longitude $031.66569^{\circ} \mathrm{E}$ and on an elevation of $1927 \mathrm{~m}$. Vimbwa refining furnace outcrop which was the first to be seen and nearest to Miangarua furnace 1 is $5.62 \mathrm{~km}$. Pottery and slag samples were collected from the surface for identification and analysis, with the aim of understanding the technology and thereby opening up areas for further research.

\section{Description of Miangarua Site}

The site is located on latitude $08.34880^{\circ} \mathrm{S}$ and longitude $031.67115^{\circ} \mathrm{E}$ and $4.47 \mathrm{~km}$ away from the nearest village, Liapona and is $11.22 \mathrm{~km}$ away from Kaengesa Ward bus stand. The site lies on a low hill that forms part of the foothill of the Sumbawanga folding mountains on Mr. Victor Kapusi's farm. The slope of the site is to the north in the direction of a stream, which is $155 \mathrm{~m}$ away. The site consists of great distribution quantities of iron slag, tuyères and tuyère pieces, furnace fragments, two still standing furnaces, one collapsed furnace and other archaeological materials. On the eastern corner of furnace \#1, is a mound that was partly dug probably for the construction of mud bricks. Where the furnace had collapsed the furnace base is surrounded by heaps of slag and tuyère. Human settlement is sparse as four houses can be sited from the surroundings and the area is being exploited for agricultural and pastoral production. Iron smelting in this area must have been practiced on a full industrial scale to meet regional demands given the quantity and scatter of metallurgical debris in and around the site. Surface collection of slag, tuyère fragments, daub and furnace wall debris was gathered, counted, weighed, recorded and left behind.

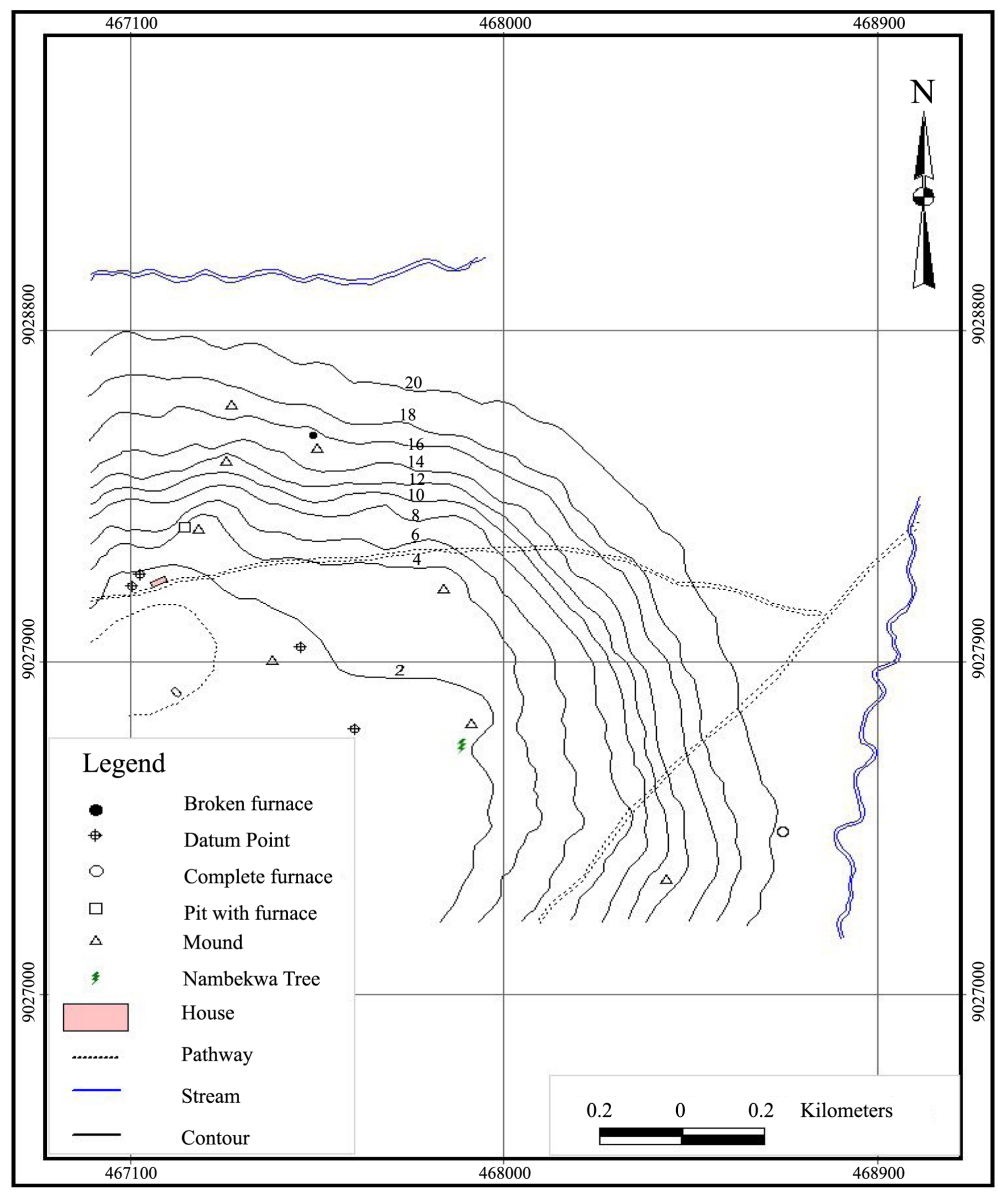

Figure 2. Map of Miangarua site showing the contour lines and archaeological features mentioned in the text. 


\section{Malungu Furnace Description}

This was a tall, tapering, induced (natural) draught furnace called Ilungu (singular) Malungu (plural) in Swahili (Figure 3). It measures $2.71 \mathrm{~m}$ from the eastern side and $2.41 \mathrm{~m}$ from the western side from ground to top but measured $3.09 \mathrm{~m}$ after excavation. The difference in height can be due to soil deposition from the western corner of the furnace as a result of erosion action or digging the mound close to the furnace for soil for construction of mud bricks as evidenced in the vicinity. The outside diameter of the furnace from the southern tuyère port to the northern tuyère port measures $170 \mathrm{~cm}$. The exterior from the eastern tuyère port to the western tuyère port measures $142 \mathrm{~cm}$ while the interior diameter of the furnace running from the southern tuyère port to the northern tuyère port measures $142 \mathrm{~cm}$ and from the eastern to the western tuyère port, it measures $136 \mathrm{~cm}$. The outside circumference of the furnace above the tip of the tuyère openings measures $500 \mathrm{~cm}, 310 \mathrm{~cm}, 287 \mathrm{~cm}, 252 \mathrm{~cm}$, and $223 \mathrm{~cm}$ and then thins away to the tip measuring $170 \mathrm{~cm}$. The width of the furnace wall from the broken part on the northern corner measures $13 \mathrm{~cm}$ and thins out to the top. Some tuyères retrieved through excavation showed heavy encrusting with vitreous slag both on the inside and the outside. This is an indication that the tuyères were used for slag taping.

The exterior surface of the furnace was rough but it seemed like it was initially smoothened or plastered but became worn-out with time. The furnace interior was highly vitrified or melted, and the walls also show signs of superimposed rings of clay during construction. A hole popularly referred to as a peephole, which we disagree with, given the temperature inside the furnace, measuring $103-111 \mathrm{~cm}$ from the ground surface was located on the eastern corner of the furnace with an internal diameter of $7.2 \mathrm{~cm}$. The furnace possesses 10 tuyère ports intact with spacing between 27 and $37 \mathrm{~cm}$. The height of the tuyère apertures ranges from $13-35 \mathrm{~cm}$.

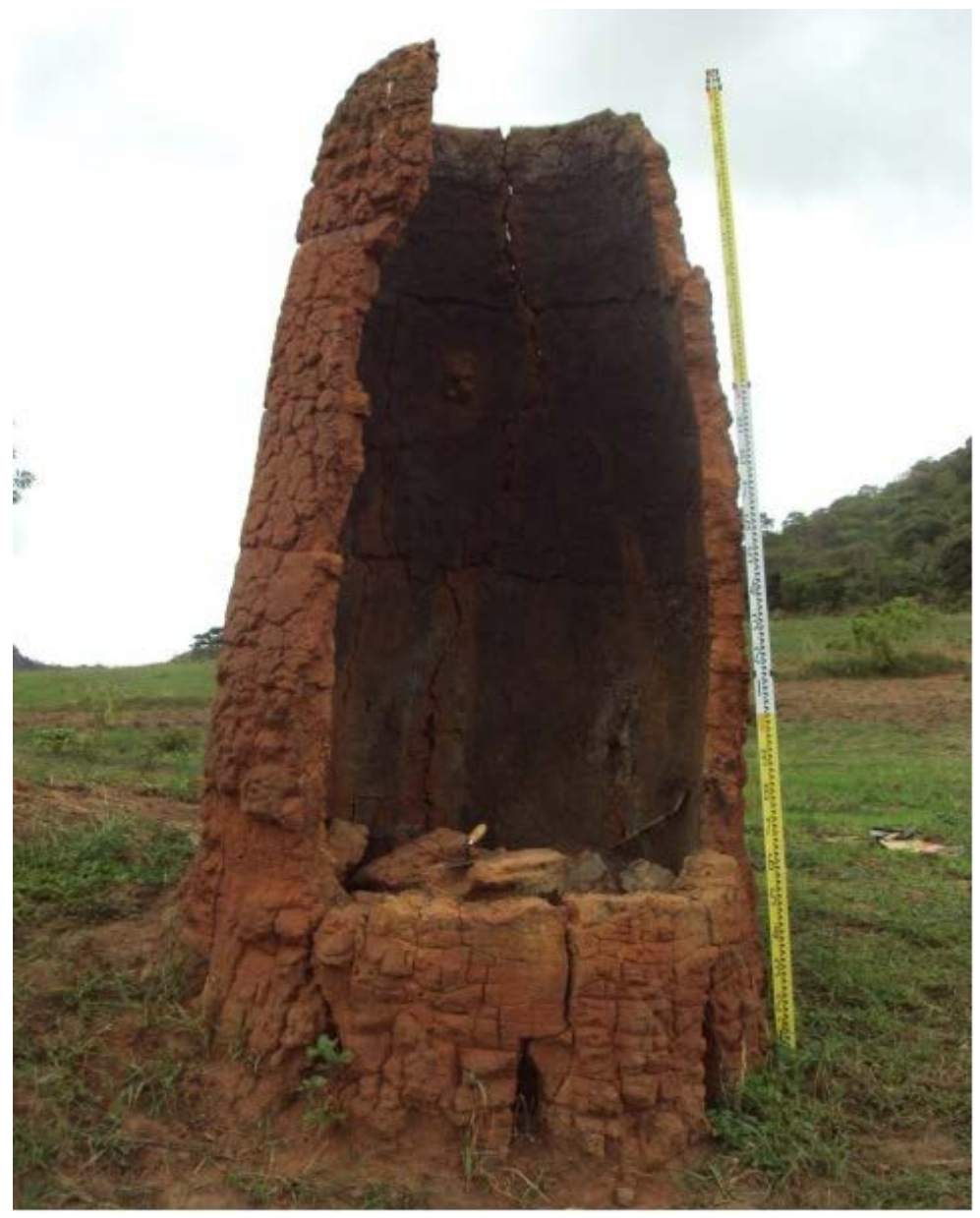

Figure 3. A view of the partly damaged Malungu furnace that was excavated. Photo: Ngonadi John Uche (2010). 


\section{Excavation: Methods and Stratigraphy}

A grid of $2 \times 5$ sq. m blocks was laid out over furnace \#1. The inside and outside of the furnace was excavated as sub-units. Excavation followed an arbitrary level of $5 \mathrm{~cm}$ in the interior of the furnace and $10 \mathrm{~cm}$ on the exterior of the furnace. After leveling from surface to $35 \mathrm{~cm}$ given the deposition of furnace wall fragments in the interior (F1\#1), an arbitrary level of $5 \mathrm{~cm}$ was adopted and excavation continued to a depth of $70 \mathrm{~cm}$. The subdatum point was established $50 \mathrm{~cm}$ from the southeastern peg of furnace 1 Unit 2 (F1\#2) and was leveled from 0 $\mathrm{cm}-70 \mathrm{~cm}$ given the sloping of the hill (Figure 4 shows a schematic description of the trench) and excavated at an arbitrary level of $10 \mathrm{~cm}$ to a depth of $90 \mathrm{~cm}$. Before excavation, the depths of the four coordinates of F1\#2 are: $\mathrm{NE}-70 \mathrm{~cm}\left(08.34877^{\circ} \mathrm{S}, 031.67117^{\circ} \mathrm{E}\right), \mathrm{NW}-70 \mathrm{~cm}\left(08.34873^{\circ} \mathrm{S}, 031.67119^{\circ} \mathrm{E}\right), \mathrm{SE}-0 \mathrm{~cm}\left(08.34875^{\circ} \mathrm{S}\right.$, $\left.031.67124^{\circ} \mathrm{E}\right)$, and $\mathrm{SW}-32 \mathrm{~cm}\left(08.34878^{\circ} \mathrm{S}, 031.67116^{\circ} \mathrm{E}\right)$. Given the fragile nature of the furnace, a $5 \mathrm{~cm}$ amount of soil was left in and around the furnace to avoid collapsing. Evidence of iron slag was more pronounced on the northwestern side of the furnace confirming the initial suggestion of slag tapping. The soils from the excavation were screened using a $4.5 \mathrm{~mm}$ wire mesh to trap small archaeological materials such as slag beads and the soil identified using a Munsell soil colour chart.

The interior (F1\#1) of the furnace presented below showed interestingly an overlapping and interchangeable soil colours and archaeological deposits.

Level 1: $(0$ - $35 \mathrm{~cm})$ 2.5YR 4/6 Red, 7.5YR 5/8 Strong brown and 10YR 6/6 Brownish yellow. It produced great number of charcoal and slag with little tuyère debris.

Level 2: (35 - 40 cm) 2.5YR 3/6 Dark red, 2.5YR 5/6 Light olive brown and 7.5YR 3/4 Dark brown. Two holes became visible with lots of slag and charcoal.

Level 3: (40 - 45 cm) 10YR 5/2 Grayish brown, 10YR Light yellowish brown and 10YR 6/6 Brownish yellow. Change in soil colour and decrease in tuyère fragments.

Level 4: (45 - 50 cm) 10YR 3/1 Very dark gray, 10YR 5/1 Gray, 10YR 5/2 Grayish brown and 10YR 6/8 Brownish yellow. The floor at this level was hard fired, compact and produced the highest number of slag.

Level 5: (50 - $55 \mathrm{~cm}$ ) 2.5YR 4/6 Red and 10YR 5/2 Grayish brown. Presence of charred wood measuring 17 $\mathrm{cm}-25 \mathrm{~cm}$ from the south, east and western corner of the furnace.

Level 6: (55 - $60 \mathrm{~cm}$ ) 2.5YR 3/6 Dark red and 5YR 5/1 Gray. More logs of burnt wood in a bed-like position, like a foundation.

Level 7: (60 - 65 cm) 5YR 4/4 Reddish brown. Decrease in slag, charcoal and charred wood.

Level 8: (65 - $70 \mathrm{~cm})$ 2.5YR 4/6 Red. Change in soil colour and disappearance of cultural materials.

A wall profile (Figure 5) was drawn on the exterior (F1\#2) of the furnace oriented on the southern wall running from SE-SW. The stratigraphic sequence contains tuyère fragments and slag and was made up of 4 layers

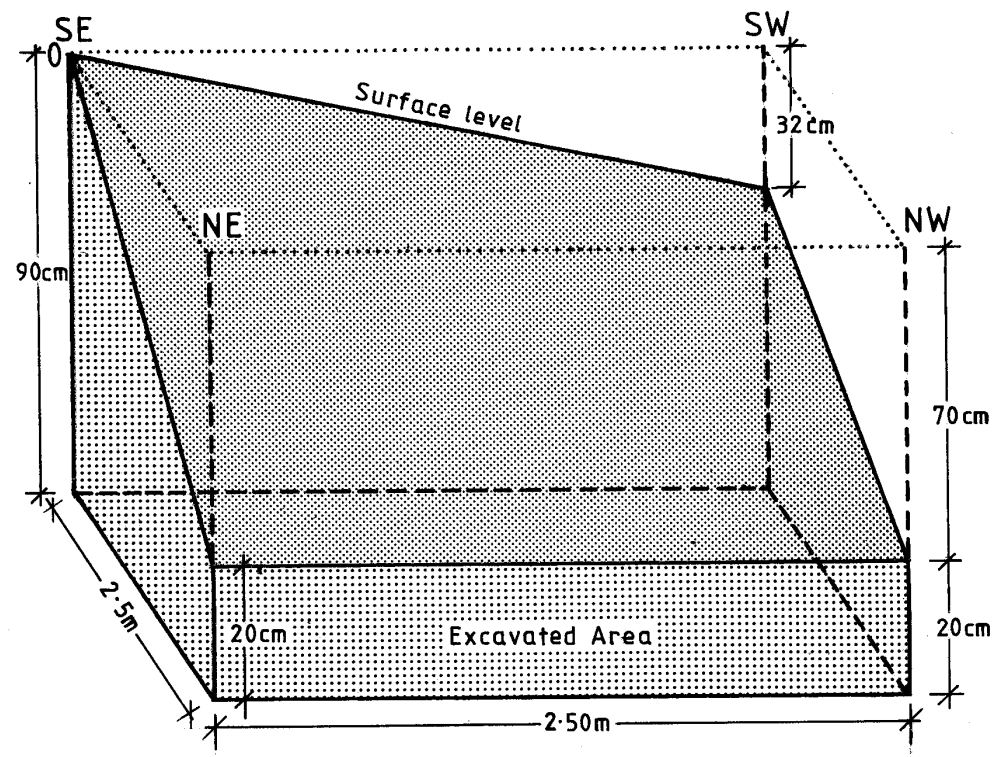

Figure 4. Schematic reconstruction of the Trench in Miangarua Site. 
(see Figure 6). The first layer, the topsoil was grayish brown (10YR 5/2). The second layer was dark brownsandy clay (7.5YR 3/4) while the third layer was reddish brown-sandy silt (5YR 4/4). Finally, the fourth layer, which was the sterile layer, was red in colour-sandy silt (2.5YR 4/6). The first three layers showed no natural layering but were very disturbed by rootlets.

\section{Discussion}

The physical attributes examination of the iron smelting slag retrieved through excavation was done using Mapunda's (2006) model with modifications. Slag with shared attributes were grouped as compound samples and analyzed as one entity. The attributes are: volume (in cc), weight (in g), density (in g/cc), morphology/shape, thermal condition, luster, porosity, magnetism, colour/streak, impression/inclusion, fragmentation, weathering, raw material and surface condition. Together with volume, weight indicates the type of technological process employed. Evidence shows that smelting slag is generally more massive and heavier than refining or smithing slag. This is because the former contains more iron than the latter. Slag excavated from the furnace is smaller and fist-sized chunks compared to the heavier chunks collected from the surface around the furnace, which is a clear evidence of iron slag tapping technology. The volumes of the slag are expected from an iron smelting furnaces of this size and suggest the furnace reuse hypothesis. The thermal condition of the slag samples indicate a

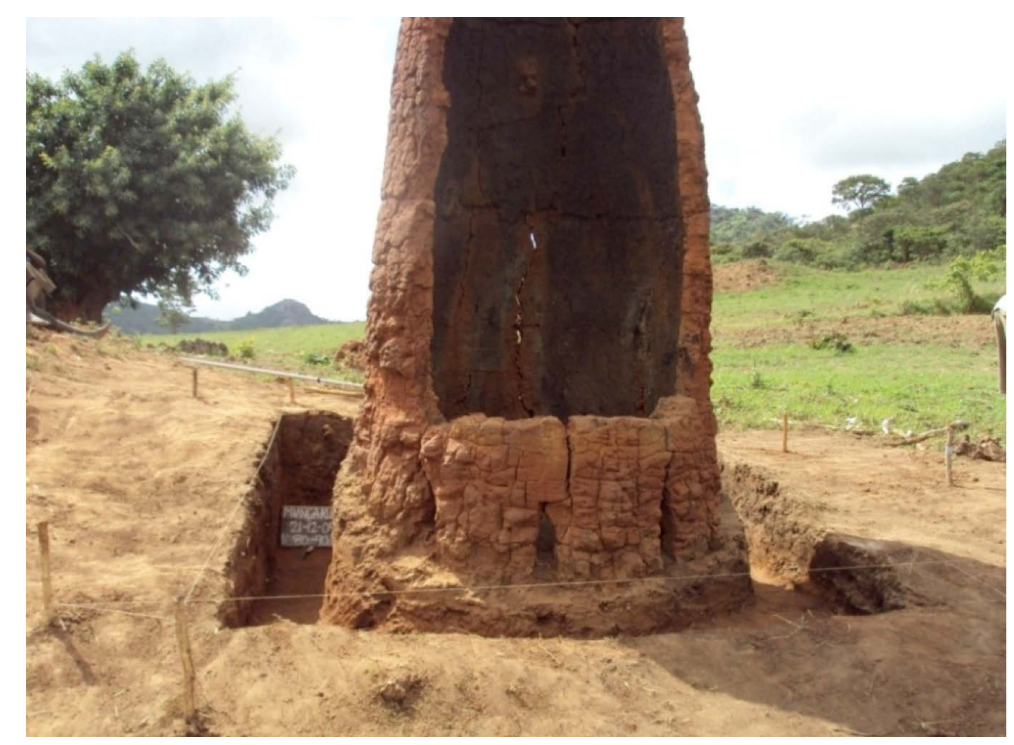

Figure 5. The exterior of the excavated trench in Miangarua site (F1\#2). Photo: Ngonadi John Uche (2010).

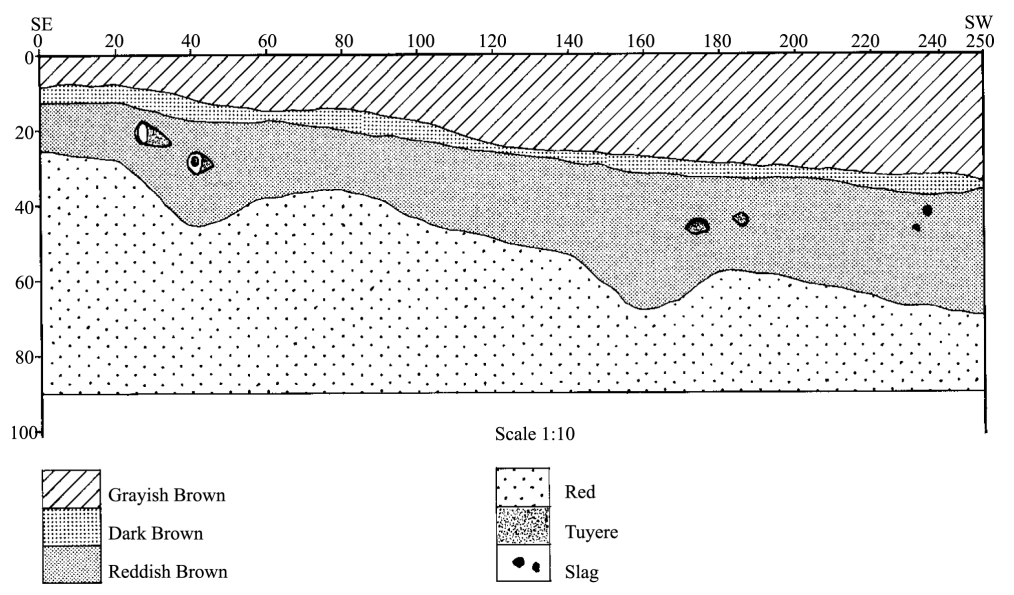

Figure 6. Southern wall profile of F1\#2, Miangarua Site. 
high frequency of molten slag technology resulted from metallurgical processes as opposed to natural processes. Four attributes were used to determine luster (ceramic, glass, metallic, greasy) and Malungu technology shows high metallic luster and the frequency of porosity is nil. Magnetism reading was used to determine whether the slag is ferrous or nonferrous and efficiency of the reduction technique-the higher the magnetic attraction the higher the content of iron (whether metallic or oxide) present in the slag and vice versa. The iron slag possess low rate of magnetism, which indicates efficient smelting technology practiced on the plateau. Malungu furnaces are constructed using tertiary clay, sited very far from residential area and are not more than 300m away from a water source.

A total of 1157 complete tuyères (measuring $18-22 \mathrm{~cm}$ ) and tuyère fragments were retrieved with smooth surfaces, clay texture and sand as the tempering material (for summary see Table 1). The internal diameter ranges from $3.4-4.2 \mathrm{~cm}$ and the external diameter are $6.1-7.6 \mathrm{~cm}$ with a thickness of $2-2.9 \mathrm{~cm}$. Tuyère from this technology has heavy slag coating. A good quantity of charcoal and bark wood strips from minute particles to pieces measuring $17-25 \mathrm{~cm}$ at the base of the furnace was noted. These wooden strips are ritual medicine, vizimba, made at the center of Malungu furnaces to ensure the success of the smelt. Sometimes it is to protect against otherwise uncontrollable, sinister forces that might harm the smelt (Schmidt \& Avery, 1983, Davison \& Mosley, 1988). Small pieces of stone and two hammer stones were excavated. This and other abraded stones might have been used during ore preparation and later after smelt, discarded and thrown into the furnace (Mapunda pers. comm. 2010) as against being a Later Stone Age material. The potsherds retrieved from excavation are burnished body sherds that seem to represent only a few vessels, presumably vessels used by the smelters for storing water and food.

\section{Conclusion}

The method used in arriving at the results of this investigation is based on physical observation that is usually a researcher's first line of judgment in the field before the choice of laboratory re-examination is conducted. The results for this study reveal that the Fipa used two different clay colour, reddish brown and dark brown and two different furnace morphology. As mentioned above, Malungu furnaces are sited very far from residential areas for security and concentration among the smelters in order to avoid distraction of any sort, be it sexual or family responsibility, as their energy is important for the success of the smelt. Since one of the purposes of excavation was to examine the furnace interior, learn about the height, deposition of metallurgical materials and the type of ritual practices obtainable. The furnace interior shows rings of slag encrusting evidence of furnace reuse. The slag from this study shows that Malungu produced heavy and very big slag with evidence of flow marks and a high frequency of metallic luster. It also has a low rate of magnetism; an indication that the smelting technology employed can correctly be rated as efficient. Vizimba was identified at center of the furnace interior at levels 50 - 60 $\mathrm{cm}$ - showing evidence of ritual practice. Ethnographic and archaeological studies indicate that medicines were used almost universally to ensure the success of smelting. In most cases, usually these were organic materials, each ingredient perhaps symbolizing some property to be transferred to the firing process or the product (Davison \& Mosley, 1988).

It has been argued (Humphris et al., 2007) that the slag deposited on the landscape as well as its contents is not necessarily based on the composition of its formation processes in the furnace but based on human decisions. Such choices during smelting processes or pattern include the inclusion of fluxing materials, which may have

Table 1. Summary of materials recovered and their weights.

\begin{tabular}{|c|c|c|c|c|c|c|c|c|}
\hline & Slag & Slagy Tuyère & $\begin{array}{c}\text { Tuyère/ } \\
\text { Tuyère } \\
\text { Fragments }\end{array}$ & $\begin{array}{l}\text { Charcoal/ } \\
\text { Burnt Wood }\end{array}$ & $\begin{array}{c}\text { Furnace Wall } \\
\text { Debris }\end{array}$ & Lithics & Potsherds & Daub \\
\hline $\begin{array}{l}\text { Surface } \\
\text { Collection }\end{array}$ & 1781 & 215 & 441 & 0 & 42 & 0 & 4 & 0 \\
\hline $\begin{array}{l}\text { Furnace Interior } \\
\text { (F1\#2) }\end{array}$ & 3023 & 32 & 52 & 997 & 119 & 8 & 3 & 9 \\
\hline $\begin{array}{c}\text { Furnace } \\
\text { Exterior (F1\#2) }\end{array}$ & 1175 & 66 & 351 & 0 & 9 & 4 & 6 & 15 \\
\hline Weight (kg) & 661.9 & 225.6 & 32.3 & 3 & 471.2 & 5 & - & - \\
\hline
\end{tabular}


had indirect contribution to the formation of the resultant slag. The degree of reduction is a function of fuel-toore ratios and airflow through the furnace; both parameters are directly controlled first by the furnace design, and then the head smelter during the smelt, etc. Similarly, the addition of quartz sand as a flux in smelting extremely rich magnetite ore must have evolved in some way.

\section{Acknowledgements}

The material published in this paper formed part of a Master of Arts dissertation submitted in partial fulfillment of the requirements of the degree of MA in Archaeology at the University of Dar es Salaam funded by SIDA/ SAREC through African Archaeology Network. The authors are grateful to Professor Bertram Mapunda and Professor Felix Chami for their various contributions.

\section{References}

Barndon, R. (2001). Masters of Metallurgy-Masters of Metaphors: Ironworking among the Fipa and Pangwa of Southwestern Tanzania. Bergen: University of Bergen.

Childs, S. T. (1991). Style, Technology and Iron-Smelting Furnaces in Bantu Speaking Africa. Anthropological Archaeology, 10, 332-359. http://dx.doi.org/10.1016/0278-4165(91)90006-J

Davison, S., \& Mosley, P. N. (1988). Iron-Smelting in the Upper North Rukuru Basin of Northern Malawi. Azania, 23, 5799. http://dx.doi.org/10.1080/00672708809511387

Greig, R. C. H. (1937). Iron Smelting in Fipa. Tanganyika Notes and Records, 4, 77-81.

Humphris, J. E., Rehren, T., Charlton, M., Chirikure, S., Ige, A., \& Veldhuijzen, H. A. (2007). Decisions Set in Slag: The Human Factor in African Iron Smelting. Metals and Mines: Archaeometallurgy, 211-218.

Kense, F. J. (1983). Traditional African Iron Working. Calgary: University of Calgary.

Lechaptois, M. (1913). Aux Rives Du Tanganyika. Algiers: Maison-Carée.

Mapunda, B. B. B. (1995). An Archaeological View of the History and Variation of Ironworking in Southwestern Tanzania. Ph.D. Thesis, Florida: University of Florida.

Mapunda, B. B. B. (2003). Fipa Iron Technologies and Their Implied Social History. In C. M. Kusimba, \& S. B. Kusimba (Eds.), East African Archaeology: Foragers, Potters, Smiths and Traders. Pennsylvania: University of Pennsylvania Museum. http://dx.doi.org/10.9783/9781934536261.71

Mapunda, B. B. B., (2010). Contemplating the Fipa Iron Working. Kampala: Fountain Publishers.

Ngonadi, J. U. (2010). Relationship between Furnace Structure and Slag Properties: The Case of Fipa and Nyiha Iron Smelting Technology. MA Dissertation, Dar es Salaam: University of Dar es Salaam.

Robert, J. M. (1949). Croyances et coutumes magico-Religieuses des Wafipa païens. Tabora: Tanganyika Mission Press.

Schmidt, P. R., \& Avery, D. H. (1983). More Evidence for an Advanced Prehistoric Iron Technology in Africa. Field Archaeology, 10, 421-434. http://dx.doi.org/10.1179/009346983791504228

Wembah-Rashid, J. (1969). Iron Workers of Ufipa. Bulletin of International Committee of Urgent Anthropological Research, 11, 65-72.

Willis, R. G. (1966). The Fipa and Related Peoples of Southwest Tanzania and Northeast Zambia. London: International African Institute.

Willis, R. G. (1981). A State in the Making: Myth, History, and Social Transformation in Precolonial Ufipa. Bloomington: Indiana University Press.

Wise, R. (1958a). Iron Smelting in Ufipa. Tanganyika Notes and Records, 50, 106-111.

Wise, R. (1958b). Some Rituals of Iron-Making in Ufipa. Tanganyika Notes and Records, 51, 232-238.

Wyckaert, A. (1914). Forgerons Païens et Forgerons Chrétiens Au Tanganyika. Anthropos, 9, 371-380. 
Scientific Research Publishing (SCIRP) is one of the largest Open Access journal publishers. It is currently publishing more than 200 open access, online, peer-reviewed journals covering a wide range of academic disciplines. SCIRP serves the worldwide academic communities and contributes to the progress and application of science with its publication.

Other selected journals from SCIRP are listed as below. Submit your manuscript to us via either submit@scirp.org or Online Submission Portal.
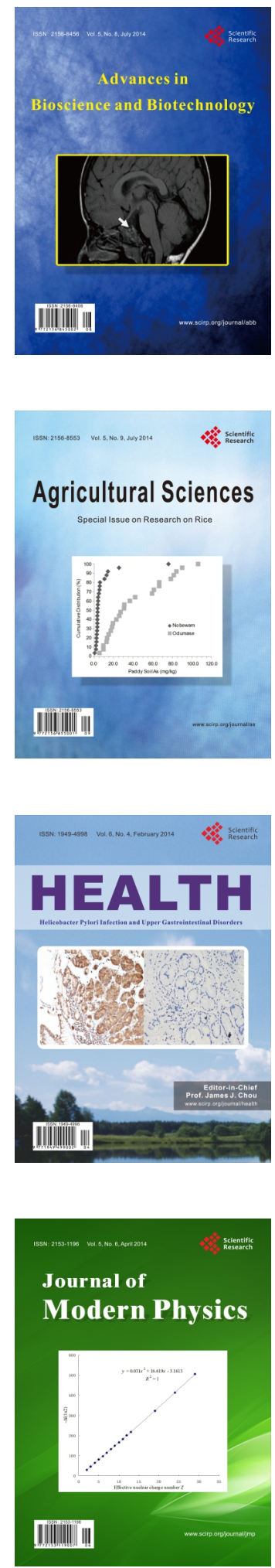
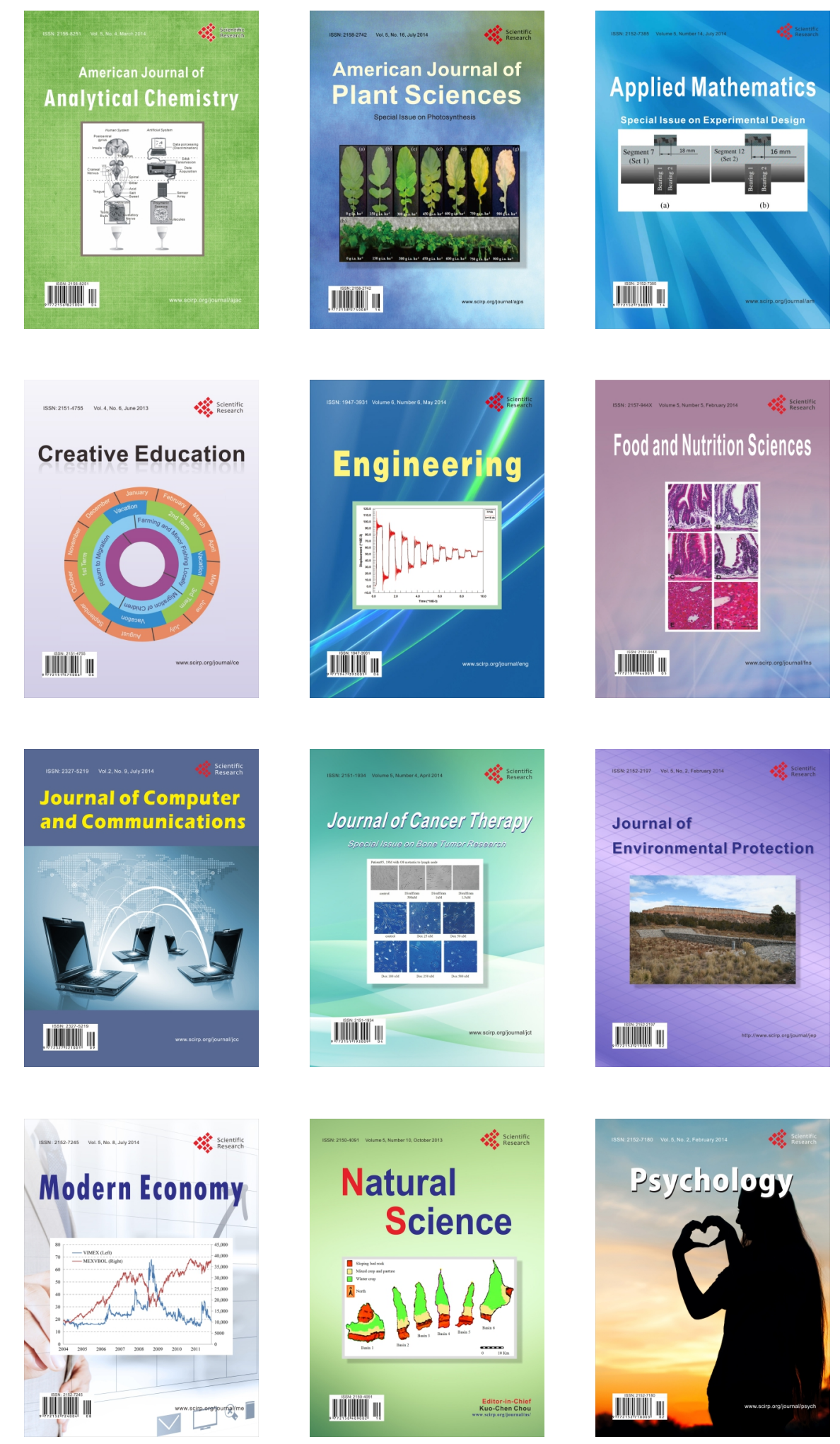